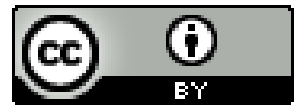

\title{
MEMÓRIAS DO ATELIER DE MODA AFRO: NARRATIVAS DE UMA PRÁTICA EDUCATIVO-CRÍTICA
}

\author{
Francis Musa Boakari ${ }^{1}$ \\ Universidade Federal do Piauí(UFPI), Programa de Pós Graduação em Educação \\ (PPGED). \\ Francilene Brito da Silva ${ }^{2}$ \\ Universidade Federal do Piauí (UFPI), Programa de Pós Graduação em Educação
}

(PPGED).

\section{L'Hosana Céres de Miranda Tavares ${ }^{3}$ \\ Universidade Federal do Piauí (UFPI), Programa de Pós-Graduação em Educação \\ (PPGED).}

Resumo: O racismo brasileiro gera perdas e danos na vida das pessoas e, muitas vezes, isso não é discutido no ensino superior de moda, bem como nos espaços educativos sociais. Este texto é um dos frutos de uma pesquisa na área de Educação, que foi realizada como uma prática educativa que interferiu no Curso Superior em Tecnologia do Design de Moda do Instituto Federal de Educação Ciência e Tecnologia do Piauí (IFPI), Campus Teresina Zona Sul (CTZS), no espaço educativo Memorial Esperança Garcia em 2019, e culminou com um desfile de Moda Afro a partir das experiências do Atelier de Moda Afro. Participaram da pesquisa dezenove discentes. Foram escolhidas apenas duas

\footnotetext{
${ }^{1}$ Nascido em Serra Leoa, é brasileiro naturalizado, e se considera estudante dos cotidianos brasileiros. Continua docente dos Programas de Graduação e Pós-graduação para Preparação de Profissionais das Educações na Universidade Federal do Piauí, Campus Teresina, onde coordena o Núcleo de Estudos e Pesquisas sobre gênero, educação e afrodescendência (RODA GRIÔ-GEAfro) desde 2010. E-mail: musabuakei@yahoo.com ; ORCID: https://orcid.org/0000-0002-5786-2387
}

\footnotetext{
${ }^{2}$ Afrodescendente, doutora em Educação UERJ (2017), mestre em Educação UFPI (2011) Especialista em Teoria do Conhecimento UFPI (2004) e Licenciada em Educação Artística com Habilitação em Artes Plásticas pela UFPI (2001). Atualmente é Professora da Universidade Federal do Piauí do Departamento de Artes, Centro de Ciências da Educação, e uma das líderes-pesquisadora do Núcleo de Estudos e Pesquisas Roda Griô - GEAfro: Gênero, Educação e Afrodescendência (UFPI) e membro do Grupo de Pesquisa Culturas e Identidades no Cotidiano (UERJ). Estuda temas sobre Educação e Diversidade a partir de: Arte e Afrodescendência como Narrativas (escritas, orais e imagéticas) decoloniais e cotidianas. E-mail: artlenha@yahoo.com.br ; ORCID: https://orcid.org/0000-0001-9655-6633

${ }^{3}$ Doutoranda em Educação pelo Programa de Pós-Graduação em Educação (PPGED) da Universidade Federal do Piauí (UFPI), Designer de Moda, professora do Curso Superior em Tecnologia do Design de Moda do Instituto Federal de Educação Ciência e Tecnologia do Piauí (IFPI) e membro da Associação Brasileira de Pesquisadores Negros (ABPN). E-mail: lhosana.ceres@ifpi.edu.br ; ORCID: https://orcid.org/0000-0001-6986-1130
} 

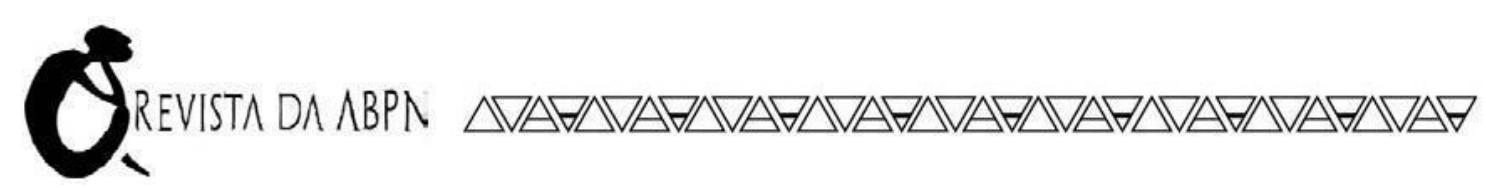

histórias por serem representativas do sentimento do grupo. Dialogamos com autoras/es como Lélia Gonzalez (1984) e Paulo Freire (1979; 2011). Percebemos, na análise dialógica dessa prática educativa de intervenção, dez tipos de corpos narrados em momentos da vida das duas partícipes coincidentes com as práticas racistas brasileiras e suas superações.

Palavras-Chave: Moda Afro; Racismo; Consciência Crítica; Memórias.

\title{
MEMORIES OF THE AFRO FASHION WORKSHOP: NARRATIVES OF AN EDUCATIONAL-CRITICAL PRACTICE
}

\begin{abstract}
Brazilian racism generates losses and damages in people's lives and, often, this is not discussed in higher education in fashion, as well as in social educational spaces. This text is one of the fruits of a research in the area of Education, which was carried out as an educational practice that interfered in the Higher Course in Fashion Design Technology at the Federal Institute of Education, Science and Technology of Piauí (IFPI), Teresina Zona Sul Campus (CTZS), at the Memorial Esperança Garcia educational space in 2019, and culminated with an Afro Fashion show based on the experiences of the Atelier de Moda Afro. Nineteen students participated in the research. Only two stories were chosen because they were representative of the group's feeling. We dialogued with authors such as Lélia Gonzalez (1984) and Paulo Freire (1979; 2011). In the dialogical analysis of this educational intervention practice, we perceive ten types of bodies narrated in moments in the two participants' lives that coincide with Brazilian racist practices and their overcoming.
\end{abstract}

Keywords: Afro Fashion; Racism; Critical Consciousness; Memories.

\section{MEMORIAS DEL TALLER DE MODA AFRO: NARRACIONES DE UNA PRÁCTICA EDUCATIVO-CRÍTICA}

Resumen: El racismo brasileño genera pérdidas y daños en la vida de las personas y, muchas veces, esto no se discute en la educación superior en la moda, así como en los espacios socioeducativos. Este texto es uno de los frutos de una investigación en el área de Educación, que se llevó a cabo como una práctica educativa que interfirió en el Curso Superior en Tecnología de Diseño de Moda en el Instituto Federal de Educación, Ciencia y Tecnología de Piauí (IFPI), Campus Teresina Zona Sul (CTZS), en el espacio educativo Memorial Esperança García en 2019, y culminó con un desfile de Moda Afro basado en las experiencias del Atelier de Moda Afro. Diecinueve estudiantes participaron en la investigación. Solo se eligieron dos historias porque eran representativas del sentimiento del grupo. Dialogamos con autores como Lélia González (1984) y Paulo Freire (1979; 2011). En el análisis dialógico de esta práctica de intervención educativa, percibimos diez tipos de cuerpos narrados en momentos de la vida de los dos participantes que coinciden con las prácticas racistas brasileñas y sus superaciones.

Palabras-clave: Moda Afro; Racismo; Conciencia Crítica; Recuerdos. 


\title{
O
}

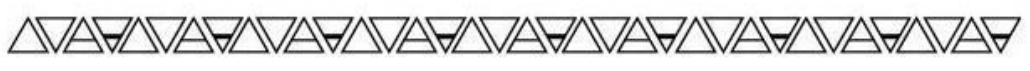

\section{SOUVENIRS DE L'ATELIER DE MODE AFRO : RÉCITS D'UNE PRATIQUE ÉDUCATIVE-CRITIQUE}

Résumé : Le racisme brésilien génère des pertes et des dommages dans la vie des gens et, souvent, cela n'est pas discuté dans l'enseignement supérieur de la mode, ainsi que dans les espaces éducatifs sociaux. Ce texte est l'un des fruits d'une recherche dans le domaine de l'éducation, qui a été menée en tant que pratique éducative qui a interféré dans le cours supérieur de technologie du design de mode à l'Institut fédéral d'éducation, de science et de technologie de Piauí (IFPI), Teresina Zona Sul Campus (CTZS), à l'espace éducatif Memorial Esperança Garcia en 2019, et a culminé avec un défilé Afro Fashion basé sur les expériences de l'Atelier de Mode Afro. Dix-neuf étudiants ont participé à la recherche. Seules deux histoires ont été choisies parce qu'elles étaient représentatives du sentiment du groupe. Nous avons dialogué avec des auteurs tels que Lélia Gonzalez (1984) et Paulo Freire $(1979$; 2011). Dans l'analyse dialogique de cette pratique d'intervention éducative, nous percevons dix types de corps racontés dans des moments de la vie des deux participants qui coïncident avec les pratiques racistes brésiliennes et leurs dépassements.

Mots-clés : Mode Afro; Racisme; Conscience Critique; Souvenirs.

\section{MEMÓRIAS DO ATELIER DE MODA AFRO: NARRATIVAS DE UMA PRÁTICA EDUCATIVO-CRÍTICA}

\begin{abstract}
Está escuro e úmido e chove o dia todo. Eu amo dias como este. Enquanto estou deitada na cama sou capaz de aprofundar-me no meu íntimo. Talvez hoje escreverei deste âmago profundo. Enquanto tateio as palavras e uma voz para falar do escrever, olho para minha mão escura, segurando a caneta, e penso em você a milhas de distância segurando sua caneta. Você não está sozinha.
\end{abstract}

(ANZALDÚA, 2000, p. 232)

Ao ler essa frase de Glória Anzaldúa (2000), olhamos para as nossas mãos e imediatamente relembramos das muitas mãos escuras como as nossas, e claras também, que adentraram aquele atelier, preparado por uma de nós para recebê-los/as. Lembramos, com mais intensidade ainda, daqueles corpos emocionados, quase dançantes, felizes em participar daquelas tardes de preparação para construção do desfile de moda afro. E, com o peito apertado, lembramos daqueles olhos marejados ou distantes, das vozes embargadas contando histórias de suas vidas; lembramos do silêncio que pairava no ar após cada narrativa, como se os demais sentissem o mesmo nas falas de suas/seus colegas com as/os quais revivíamos cada minuto daquelas narrativas que deixaram para sempre 
cicatrizes. Cicatrizes que nos fizeram sofrer cada vez que relembrávamos, mas, ao mesmo tempo, foram capazes de nos deixar mais fortes, mais preparados/as para as inúmeras batalhas que ainda teremos de enfrentar. Pois, a guerra ainda não acabou, as armas são escassas e temos que ter o maior cuidado com as que estão em nossas mãos, não podemos desperdiçá-las. Mas, temos certeza, não estamos sozinhas/os!

Diante disso, encontramos forças para pontuar a situação social do Brasil com relação aos racismos sofridos por mais da metade da sua população. A Agência IBGE Notícias (2019), na sua última atualização sobre desigualdade brasileira, informou que, em 2018, 99\% do total de moradores do país se declararam pretos, pardos e brancos classificação do Instituto Brasileiro de Geografia e Estatística (IBGE). Desse percentual, a população que se declarou preta representou 9,3\%; parda, 46,5\%; e 43,1\% branca. Neste texto, consideramos as partícipes que colaboraram com as narrativas dentro do grupo que se declararam parte da população preta e parda, que denominamos de afrodescendentes por estarmos cientes de que não conversamos com dados, e sim com pessoas com descendências negadas pelo racismo institucional e estrutural nesse país. Entendemos que o termo afrodescendente engloba a ancestralidade dessas pessoas, pois, conforme fala Henrique Cunha Júnior “As africanidades são a forma de consideramos os acervos do passado, transformado no presente, quanto às formas materiais e imateriais da herança africana na cultura brasileira" (CUNHA JÚNIOR 2013, p. 17). Desse modo, falar de afrodescendência nas rodas de conversa provoca o surgimento de histórias alicerçadas pela nossa descendência.

Deste contingente, os dados ainda apontam que:

Além disso, entre a população preta ou parda de 18 a 24 anos que estudava, o percentual cursando ensino superior aumentou de 2016 (50,5\%) para 2018 $(55,6 \%)$, mas ainda ficou abaixo do percentual de brancos da mesma faixa etária $(78,8 \%)$.

Nesse mesmo período, o percentual de jovens de 18 a 24 anos pretos ou pardos com menos de 11 anos de estudo e que não frequentava escola caiu de 2016 $(30,8 \%)$ para $2018(28,8 \%)$. Esse indicador era de $17,4 \%$ entre os brancos, em 2018.

No mercado de trabalho, os pretos ou pardos representavam $64,2 \%$ da população desocupada e $66,1 \%$ da população subutilizada. E, enquanto $34,6 \%$ dos trabalhadores brancos estavam em ocupações informais, entre os pretos ou pardos esse percentual era de $47,3 \%$.

O rendimento médio mensal das pessoas brancas ocupadas ( $\mathrm{R} \$ 2.796)$ foi $73,9 \%$ superior ao da população preta ou parda $(\mathrm{R} \$ 1.608)$. Os brancos com nível 
superior completo ganhavam por hora $45 \%$ a mais do que os pretos ou pardos com o mesmo nível de instrução.

A desigualdade também estava presente na distribuição de cargos gerenciais, somente $29,9 \%$ deles eram exercidos por pessoas pretas ou pardas.

Em relação à distribuição de renda, os pretos ou pardos representavam 75,2\% do grupo formado pelos $10 \%$ da população com os menores rendimentos e apenas $27,7 \%$ dos $10 \%$ da população com os maiores rendimentos.

Enquanto 44,5\% da população preta ou parda vivia em domicílios com a ausência de pelo menos um serviço de saneamento básico, entre os brancos, esse percentual era de $27,9 \%$.

Pretos ou pardos são mais atingidos pela violência. Em todos os grupos etários, a taxa de homicídios dos pretos ou pardos superou a dos brancos. A taxa de homicídios para pretos ou pardos de 15 a 29 anos chegou a 98,5 em 2017, contra 34,0 para brancos. Para os jovens pretos ou pardos do sexo masculino, a taxa foi 185,0 (AGÊNCIA IBGE NOTÍCIAS, 2019).

São esses os dados mais atuais que temos, depois de 520 anos da promessa de modernidade feita pelos portugueses na descoberta do novo mundo a que deram o nome de Ilha de Vera Cruz. Estamos falando do estudo sobre "Desigualdades Sociais por Cor ou Raça no Brasil”, que discorreu sobre as nossas desigualdades com relação ao trabalho, à distribuição de renda, à moradia, à educação, à violência e à representação política, como descrevem bem os dados citados acima. As duas jovens com as quais conversamos estão inseridas nessa realidade. Elas são alunas do Curso Superior em Tecnologia do Design de Moda no IFPI/CTZS (à época, segundo semestre de 2019, cursavam o $4^{\circ}$ semestre), estudam com muitas dificuldades, passaram bom tempo trabalhando sem frequentar a escola ou frequentando em períodos alternados, seus irmãos e familiares foram vítimas de violências das mais diversas devido serem afrodescendentes (pretos e pardos considerados pelo IBGE). O emprego nessas condições passou a ser uma utopia. Ainda mais um trabalho decente. Como nos mostram Maria Lucia da Silva e Maria Ondina da Silva Peruzzo (2020, p. 162) "pessoas negras foram eleitas bode expiatório em escala global. São depositárias de violência, negação, rejeição”.

Em 2008, o governo brasileiro assinou um acordo como membro da Organização Internacional do Trabalho (OIT) para um teste-piloto, junto com Áustria, Malásia, Tanzânia e Ucrânia, que o faria alcançar seu objetivo para discutir e procurar melhorar a Agenda do Trabalho Decente no Brasil (ESCRITÓRIO DA ORGANIZAÇÃO INTERNACIONAL DO TRABALHO, 2009). O conceito de trabalho decente está relacionado: à promoção de igualdade para mulheres e homens em produtividades, remunerações, liberdades, equidades e seguranças; à garantia de vida digna; e ao 
cumprimento de desenvolvimento e justiça social. O intuito era repensar as formas de trabalho em que mulheres, negros, indígenas, jovens, idosos, dentre outros subgrupos interseccionados, pudessem chegar a números menos desiguais com relação à população rotulada branca, de descendência europeia, entendida fenotipicamente. Desta maneira, mexia também com questões de oportunidades de empregos formais e na escolarização dos sujeitos de direitos constitucionais. Em 2020, não se fala mais nesses estudos. Há um silenciamento das questões, especialmente envolvendo mulheres e jovens afrodescendentes e indígenas. Sem falar na informalidade crescente, a olho nu, e perpetuação do trabalho indecente para esses seguimentos da população e o trabalho para crianças também pretas e pardas. Vemos explicitamente essa história global se repetir com nossas partícipes da pesquisa. Em suas narrativas (entrevistas realizadas em 2019 e transcritas em 2020) elas relatam:

[O pai da partícipe] arrendou uma parte de uma quinta de onde retirava a argila para produzir tijolos e telhas. E, segundo conversa com o dono da terra que logo virou compadre, vendeu nossa casa, único bem, para investir na olaria, logo compraria um terreno para fazer outra casa. Enquanto tinha produção, tudo estava bem para o dono da terra que recebia o pagamento do arrendamento em material que era produzido, tijolos/telhas ou os dois juntos que ele vendia, tirava o lucro dele e ponto (pronto). Do saldo que meu pai ficava tirava todas as despesas e dobrava (ou sobrava) bem pouco, resumindo: nunca foi possível comprar o tal terreno pra fazer a casa pra nossa família. Morávamos em casebre dentro da olaria. Todos trabalhávamos juntos. Serviço bem pesado. E nós ainda crianças servia para fazer mandados, (quando não estávamos ajudando na olaria). Mas nunca me toquei que houvesse uma forma de descriminação, tudo natural até quando meus pais adoeceram (Miçanga, Transcrição de áudio, linhas 105-115, 22/04/2020).

Ele, era um simples zelador, né, e foi promovido para ser porteiro. E eu não sei porquê, o que aconteceu, na época, ele foi promovido, né, por ser uma boa pessoa, por sempre chegar na hora, todo mundo gostava dele, e a promoção dele chegou, e não avisaram a ele, a direção, o diretor na época, não avisou, né. (Esquadro, Transcrição de áudio, linhas 11-20, 17/04/2020).

[...] um contratozinho na câmara que dava pra pagar o aluguel da casa, e a água e a luz, e o dinheiro só dava pra isso. Trabalhei quase cinco anos lá né. Fui estudar, fazia concurso, passava, não era chamada (Miçanga, Transcrição de áudio, linhas 600-602, 22/04/2020).

Aí na época, eu já costurando por, arrumei uma cliente em Teresina, ali na rua Treze de maio, e essa senhora perguntou se eu não conhecia uma, uma mocinha só pra ajudar na limpeza da casa. Pagava, na época um dinheiro que pra mim foi, acho que era um dinheiro enorme, né. Nunca tinha trabalhado pra pegar num dinheiro assim, e minha irmã, eu pensei, se é pra ela tá trabalhando pra ganhar uns trocadinhos só pra tá fazendo tudo que a senhora tá pedindo pra fazer e dizendo que é pra fazer aqui, aí cheguei em casa conversei com ela, expliquei pra ela e ela foi trabalhar, lá nessa, nessa casa, que e eu já fazia as costuras, que nesse 


\section{Otarsonosen}

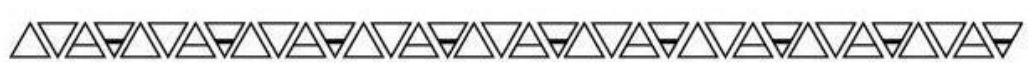

tempo eu já estava costurando de casa em casa. (Miçanga, Transcrição de áudio, linhas 365-373, 22/04/2020).

Vemos, nesses trechos, o quanto aqueles dados são reais e tornaram tudo mais difícil na vida das duas narradoras. Não há como negar o racismo nessas condições. Como escreve Sílvio Almeida (2019), que classifica o racismo a partir de três concepções, o racismo individual, institucional e estrutural, os critérios para compreendermos todos esses, bem como os dados e o contexto de fala das narrativas acima, são: as subjetividades, o Estado e a economia. A relação estabelecida entre racismo e esses três critérios pode nos fazer pensar melhor sobre as subalternizações, explorações e mortes geradas nas vidas de quem é prejudicado o tempo todo por esse mal secular. E como a escola, as instituições superiores, tecnológicas e outras irão processar esse pensar crítico? Foi a partir desta preocupação que o Atelier de Moda Afro foi pensado como oficina e desfile.

Então nos perguntamos, depois de alguns meses de seu término: o que o atelier causou em dois corpos-participantes que vivenciaram o processo de conscientização do racismo diante das subalternizações, explorações e mortes geradas em suas vidas? De início, sentimos que é preciso intervir na realidade do ensino para que nos conscientizemos do racismo que gera subalternizações, explorações e mortes diversas, para então lutar contra essas subalternizações, explorações e mortes. E, mais adiante, nos vem à memória o que Lélia Gonzalez (1984) nos escreveu sobre esse processo, como "um não-saber" que conhece, ou seja, um saber desprezado que, quando se manifesta, revela a consciência de esquecimento e de alienação racista em uma sociedade em que a mulher é um dos sujeitos mais atingidos, esse que vem acompanhado do machismo e da discriminação por classe. Assim, como a consciência ingênua ainda não é uma conscientização como liberdade, a consciência ideológica alienante e de esquecimento do racismo nos impede de acionar nossas memórias libertadoras. Muitas dessas mulheres são simplesmente "chamadas" a permanecer em lugares de subalternização e a achar isso muito normal. Então, é aí que a narrativa entra em busca da memória para falarmos das situações em que nos encontramos, como nas narrativas acima.

A partir dessa ação de revolver na memória, vemo-nos e começamos a nos perguntar se: Isso é normal mesmo? O que não é. Vamos então perceber como se deu esse processo no Atelier. Nesse processo de atiçar memórias para construir este trabalho, 
analisamos as anotações de como essas rodas de conversas aconteceram no Atelier, em seguida transcrevemos os extratos das falas de duas pessoas partícipes da pesquisa. Essa escolha se justifica pela riqueza dos seus relatos, que foram capazes de sintetizar os sentimentos despertados no grupo a partir das provocações nos/dos encontros.

Para isso, utilizamos a pesquisa qualitativa de desenhos narrativas - aquela na qual "o pesquisador coleta dados sobre as histórias de vida e experiências de algumas pessoas para descrevê-las e analisá-las (HERNANDÉZ; COLLADO; LÚCIO, 2013 p. 509). Esta estratégia metodológica pode ser vista "como um mero recontar de eventos para ser entendida como algo que entrou na biografia do falante e que é avaliado emocional e socialmente, transformando-se em experiência” (PAIVA, 2008, s. p.). As partilhas narradas pelos sujeitos da pesquisa mostram o sentido construído por eles no intuito de dar forma aos seus pensamentos. Algumas vezes, essas narrativas vêm de forma desordenada, mas vão se organizando de acordo com os acontecimentos em suas vidas (PAIVA, 2008).

\section{O ATELIER, O PROCESSO}

Onde o Atelier de Moda Afro foi instalado? Quem foram os participantes? Como ele foi pensado e o porquê? Inteirar-se de tudo sobre um desfile de moda, desde a temática, idealização das peças, modelagem, costura, escolha e ou mesmo confecção de acessórios, organização do local do desfile, local de preparação das/os modelos, escolha de maquiagens, dentre outros elementos, faz parte do arsenal de conhecimentos que devem ser compartilhados de forma sistemática em um curso de moda. Se, associado a tudo isso, formos capazes de fazer com que os educandos reflitam sobre a importância social da moda, se algumas temáticas como a afrodescendência e racismo forem realmente (re)pensadas, poderemos ter profissionais designers mais críticos, e com isso, estaremos nos preparando para vivermos num ambiente em que a alteridade, o trabalho decente, a justiça e a vida sejam a marca, o mote, a prioridade da mensagem na passarela.

Foi pensando nesse mote que idealizamos o atelier de práticas educativas, um curso de extensão, cadastrado junto ao Instituto Federal de Educação Ciência e Tecnologia do Piauí (IFPI), cujas atividades foram ministradas no Memorial Esperança Garcia, um espaço educativo do Estado. O curso de início foi pensado com uma carga de 
60 horas-aulas, sendo que dessas 20 eram destinadas ao estudo da temática "afrodescendência". Cumpre ressaltar que o empenho do grupo foi tão grande que essa carga não foi suficiente, pois muitas atividades foram desenvolvidas fora desta, o que nos obrigou a fazer uma alteração para 100 horas.

Nesse atelier nada foi escolhido por acaso, tudo foi pensado nos mínimos detalhes, desde a escolha do local, a decoração do ambiente, a escolha dos colaboradores que nos ajudaram nas rodas de conversas, a escolha do material para construção das peças, os temas abordados, a escolha do dia para o desfile, a escolha dos corpos desfilantes, as músicas, até os lanches servidos em todas as aulas, foram pensados como prática educativa provocadora de consciência crítica ou da memória, pois estávamos pondo em prática uma metodologia por nós intitulada de "pesquisa-atelier". Nesta, escolhemos elementos que achávamos pertencentes ao que chamamos de cultura afro, quais sejam: realização da oficina em uma casa de cultura que objetiva resgatar a cultura negra piauiense; utilização das cores primárias; conversas com pessoas membro do um núcleo de estudos e pesquisas intitulado Roda Griô e com ativistas do movimento negro piauiense; discussão sobre o tema "afrodescendência"; realização do desfile no dia 22 de novembro - dia da consciência negra; escolha de corpos-participantes não comuns nas passarelas de moda; partilha de comidas de santo, dentre outros detalhes, como uma intervenção de diálogos críticos sobre afrodescendência e racismo nas inspirações das peças. Queríamos que os/as alunos/as sentissem todo o carinho dispensado em recebêlos/as. Abaixo, relacionamos alguns desses momentos de práticas educativas constantes. Cada imagem é fruto de escolhas em meio a mais de 500 fotos. Selecionamos as imagens abaixo para ajudar na explicação dos momentos vividos.

Nas fotos selecionadas abaixo, podemos perceber um pouco daquilo que chamamos de uma prática educativa com o intuito de intervir numa realidade de ensino cujas marcas racistas estão impregnadas até hoje nas instituições de ensino brasileiras.

Nesta foto da Figura 1, os estudantes do Atelier concordaram em participar de uma visita ao atelier do artista piauiense Hosteano Machado. Esse é um dos momentos do Atelier como prática-educativa. O que estamos chamando de prática-educativa se encontra nas ações que a professora escolheu como ações abertas para as mudanças, para o diálogo, para a compreensão da realidade empírica; para a memória criativa e crítica dos acontecimentos. Nesta prática educativa, o artista fala para as/os estudantes sobre o 

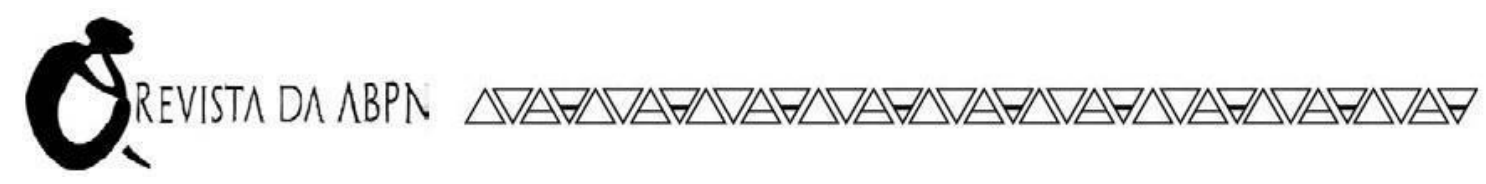

seu processo de criação. Ele diz que não é algo que ocorra por acaso, que a inspiração não aparece do nada, que os artistas ou, no caso, designers, precisam de informação, de conhecimento do que ocorre com o grupo social no qual estão inseridos, precisam saber o que aflige ou alegra, por exemplo, os grupos com os quais estão em sintonia. Ele relata o quanto teve que se informar a respeito das diásporas passadas para entender as diásporas contemporâneas, as migrações comparadas aos navios negreiros, fonte de inspiração desse seu novo trabalho. Nessa aula interventiva, por seu caráter de provocar a criatividade para a criação das peças do desfile, a intenção foi provocar a compreensão de que uma peça de roupa é uma ideia, um projeto intencional e um saber exposto. Mais adiante, continuamos a repensar sobre isso, com a próxima figura.

Figura 1: O artista piauiense, Hosteano Machado, em seu novo projeto, falando para os estudantes do Atelier de Moda Afro sobre seu processo de criação artística e a inspiração nas diásporas contemporâneas ou migrações comparadas aos navios

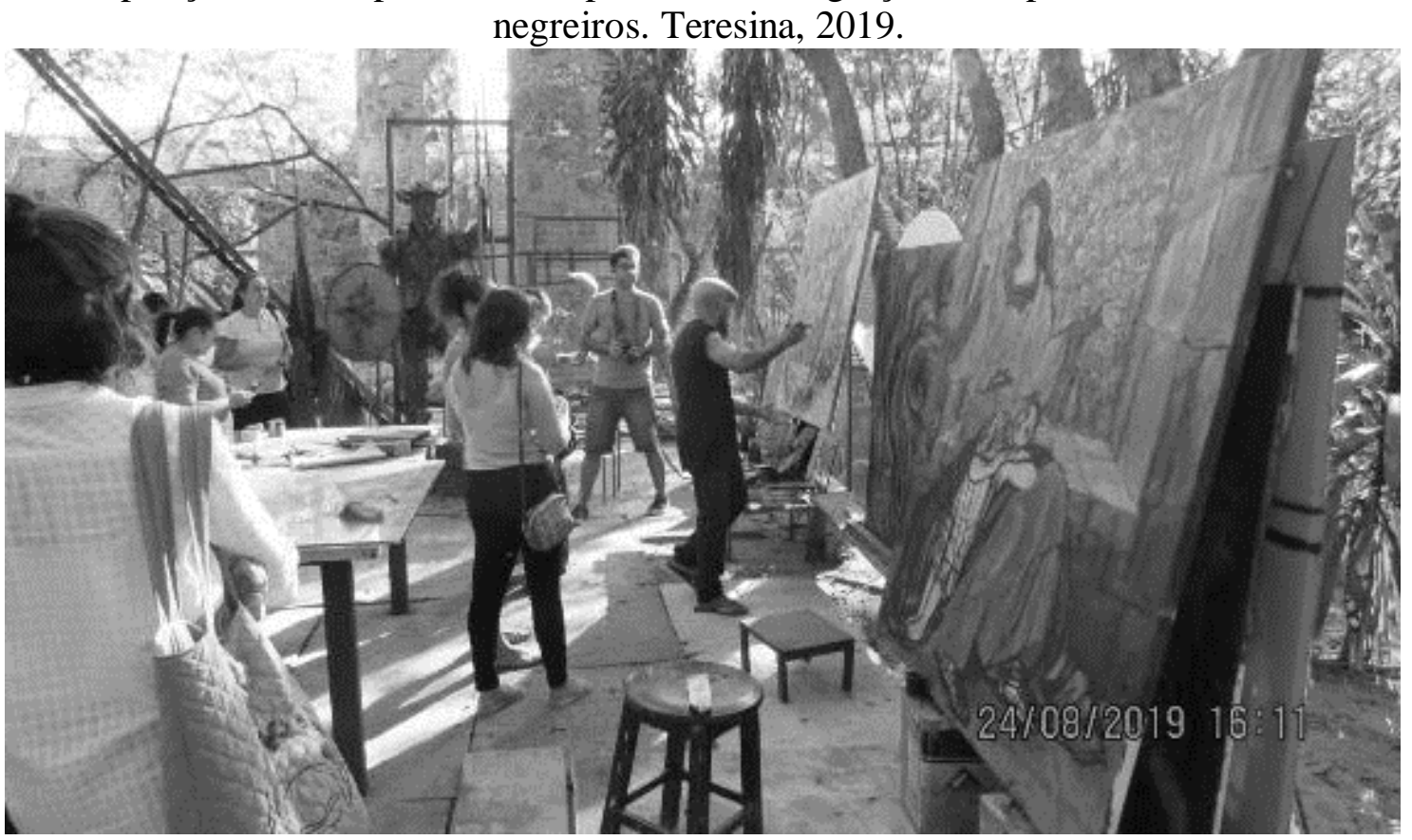

Fonte: Foto de João Paulo Brito, 2019. Acervo dos autores. 
Figura 2: A professora universitária, negra-travesti, doutoranda em Educação, Letícia Carolina falando sobre seu processo de profissionalização e de aprendizagem como pesquisadora. Teresina, 2019.

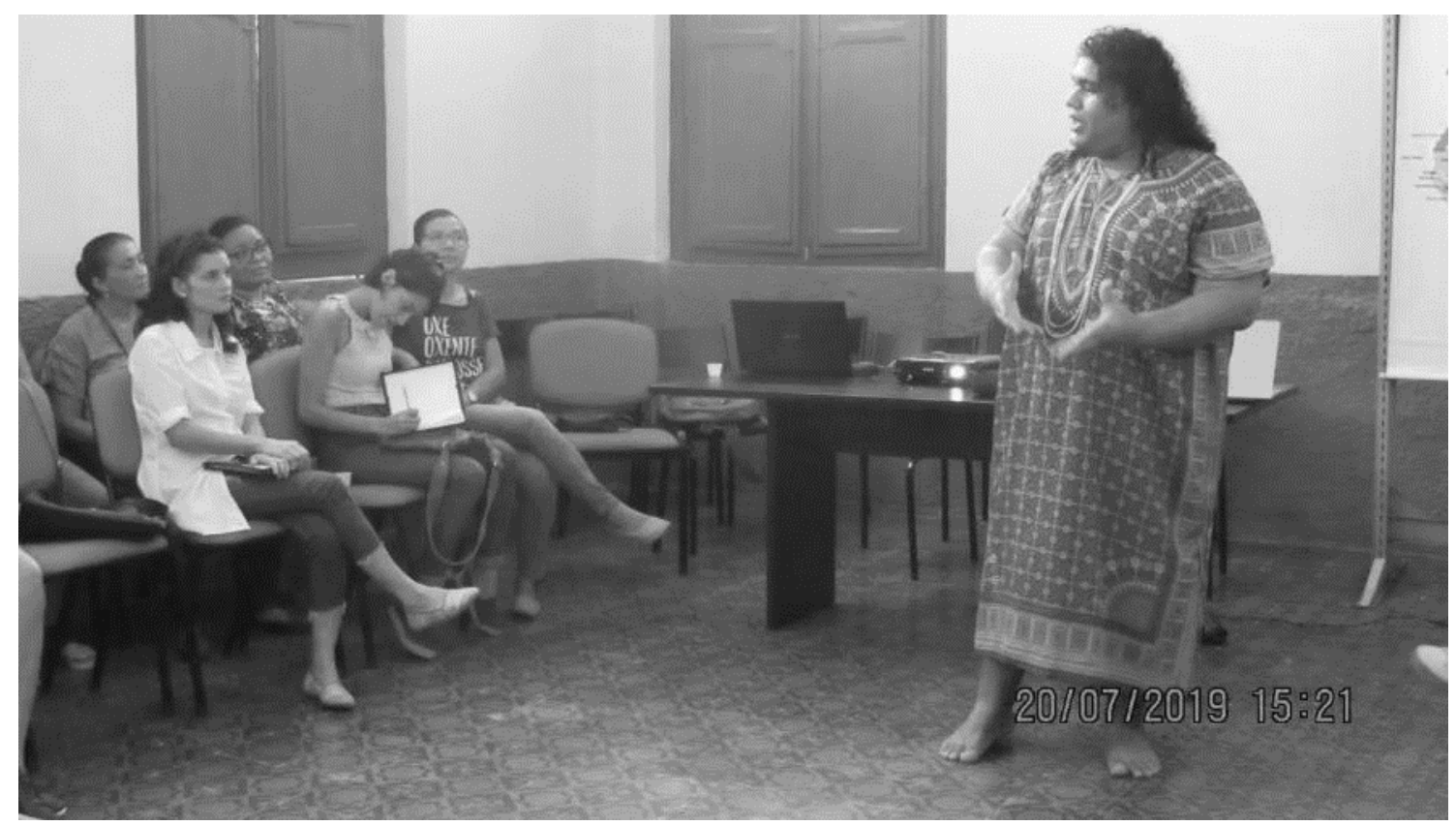

Fonte: Foto de Wendel Aguiar, 2019. Acervo dos autores.

Sabendo, então, que uma peça de roupa é mais do que imaginamos corriqueiramente, numa outra prática educativa, com narrativa quebrando paradigmas, sobre pesquisa para compor uma veste ou uma produção científica, convidamos uma pesquisadora (Figura 2). O impacto que as/os estudantes tiveram ao estarem diante da professora doutoranda Letícia Carolina foi tão grande que muitos deles chegaram a mencionar com o próprio corpo as reações, que, com o passar do tempo, foi criando afetos entre todos. A professora Letícia se sentiu impactada com a reação das/os alunas/os, mas de pronto se recompôs e falando com suavidade e carinhosamente se dirigiu ao grupo: "A reação de vocês é normal, pois nessa sociedade o lugar reservado para travestis negras e gordas como eu não é o de professora universitária e sim o da prostituição". Naquele momento, Letícia, como é hoje carinhosamente chamada por esses/essas alunos/as, ganhava o coração, o respeito e a admiração de cada uma/um, tínhamos certeza do seu valor e importância social e do seu trabalho. Ela foi convidada, posteriormente, por esse grupo para proferir a palestra de encerramento do Curso em 2019.

Aprendemos com a professora Carolina, dentre outras questões, que narrativas em processos de conscientização (FREIRE, 1979) são importantes para uma nova 
abordagem ao pesquisarmos qualquer assunto contemporâneo. Na Figura 3, tentamos mostrar outro diálogo com uma mulher afrodescendente considerada necessária no cenário piauiense.

Figura 3: A professora e mestre em Educação, Halda Regina, quando foi conversar com a turma sobre os racismos sofridos por ela e a família. Teresina, 2019.

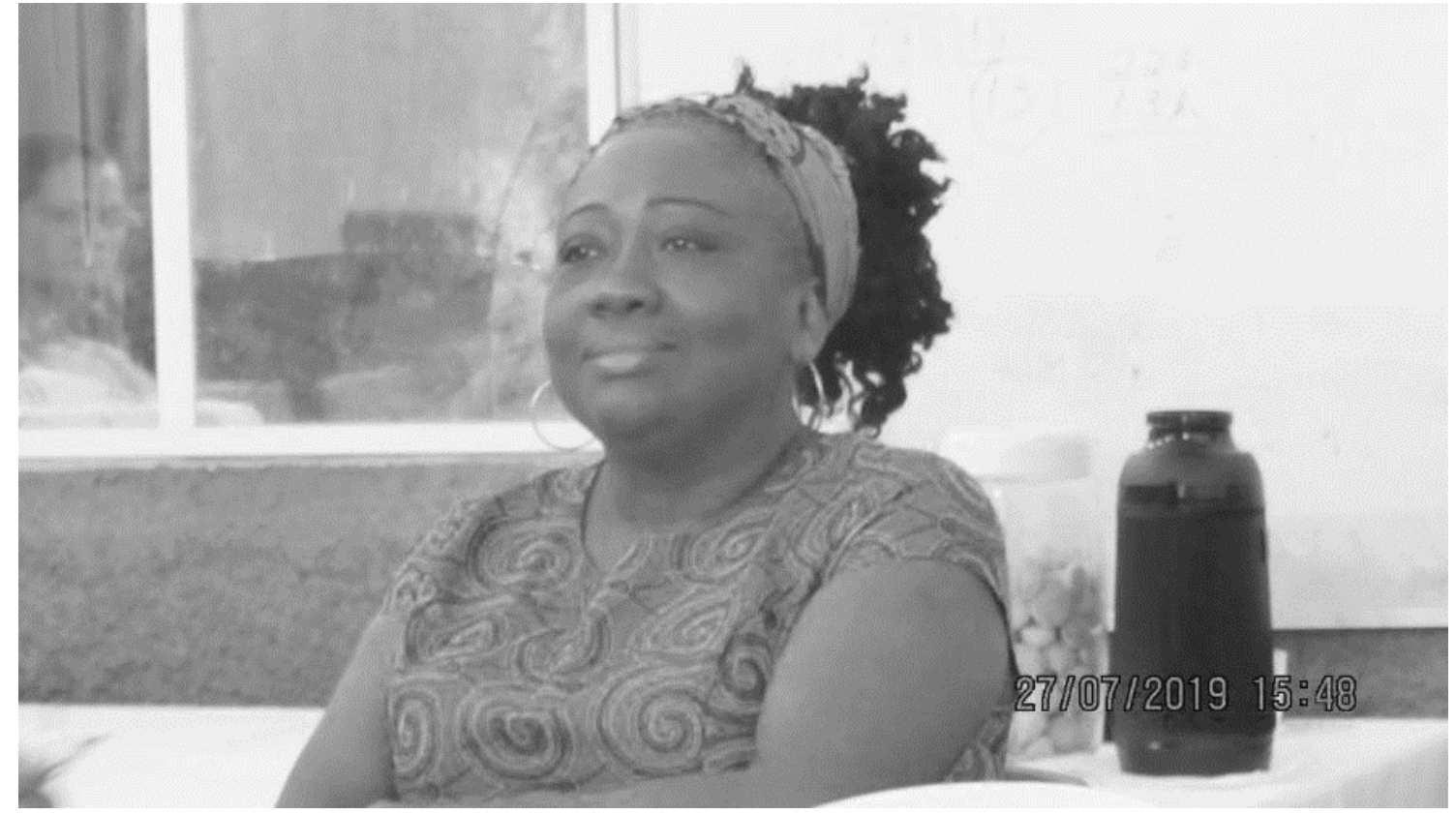

Fonte: Foto de Wendel Aguiar, 2019. Acervo dos autores.

Um outro momento muito significativo foi a fala da Profa. Maria Halda Regina, quando relata os racismos sofridos por ela e sua família, envolvendo o sistema carcerário brasileiro. A Profa. Regina faz parte do Instituto da Mulher Negra Ayabas, e foi coordenadora de Políticas Públicas para Mulheres Integrantes desse instituto. Na interação com as/os estudantes, a professora Regina falou sobre como se tornou consciente da situação racial para poder alcançar muitas das suas conquistas. Como foram acontecimentos traumáticos e íntimos de sua família nuclear, e não dispomos de sua autorização para publicação neste texto, achamos por bem não expor completamente a narrativa da professora, mas gostaríamos de enfatizar a importância educativa da conversa. Nesta mesma nota de percepção-aprendizagem continuada, lembramos a próxima fotografia, a Figura 4.

Abaixo, a ativista do Grupo Afro Cultural Coisa de Nego falando da tão propalada democracia racial brasileira. Ela convidou as alunas a acompanhá-la a um restaurante, um dos mais sofisticados de Teresina. Afirmou que, quando frequentava um 
lugar assim, os olhares se voltavam para ela como a dizer "esse lugar não deve ser frequentado por pessoas como você". "Ninguém questiona se eu tenho ou não condição de pagar". O recado é esse: "não é lugar para você." (ASSUNÇÃO AGUIAR, 27/07/2019).

Figura 3: A ativista/militante do Grupo Coisa de Nego, Assunção Aguiar, quando foi conversar com a turma sobre os racismos sofridos por ela e a família. Teresina, 2019.

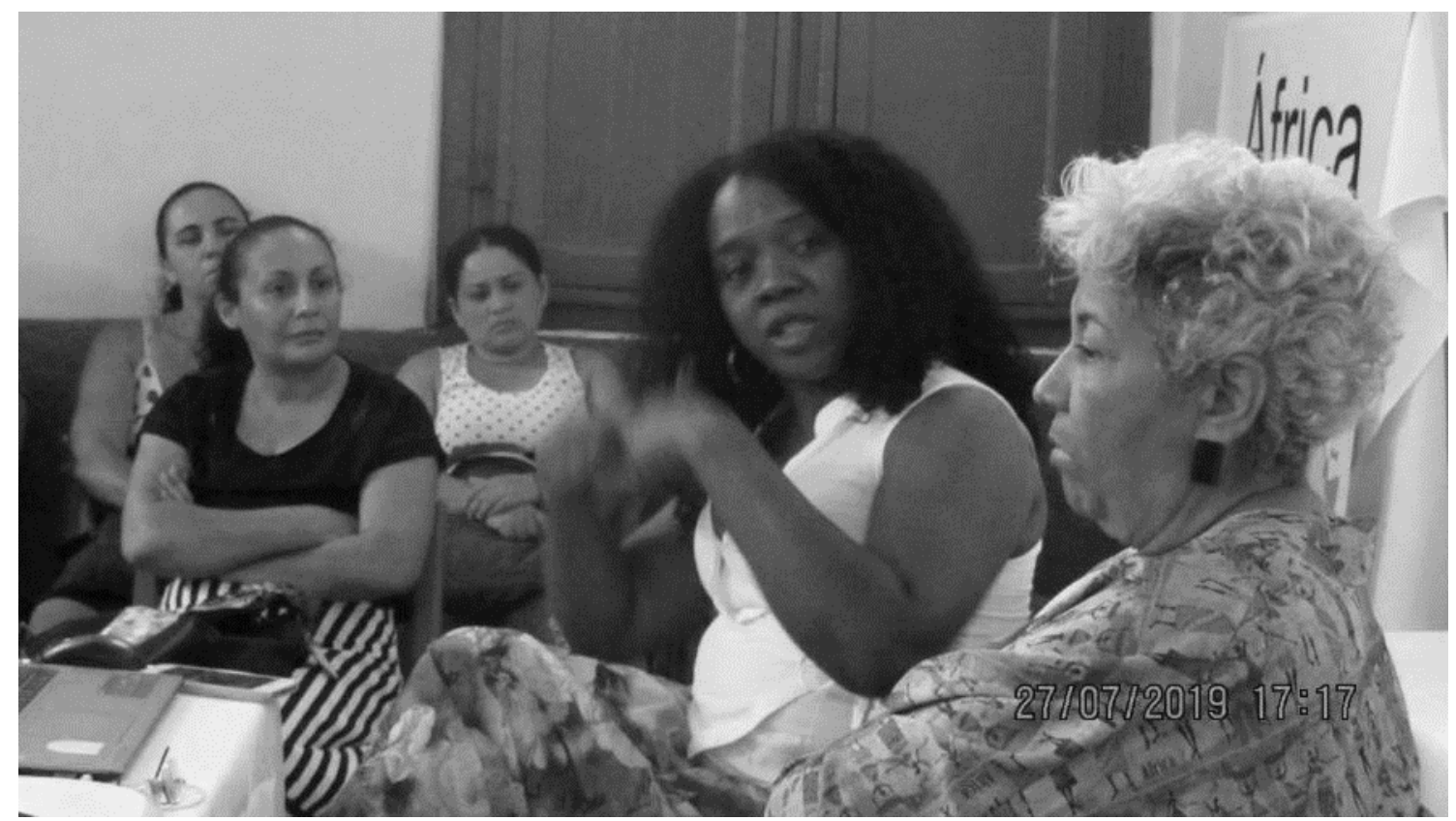

Fonte: Foto de Wendel Aguiar, 2019. Acervo dos autores.

A partir das três interações, observamos que a turma já não era mais a mesma do início do Atelier. O silêncio, as perguntas, os modos de estar coabitando por algumas horas aquele espaço da sala de atividades do grupo, de uma prática educativa integradora, de debates e maneiras de repensar o mundo iam tecendo um novo olhar, novas percepções para a construção de um desfile de moda.

A partir das conversas com Aguiar, lembramos do poder que a sociedade tem sobre nossas vidas. Mas, com suas histórias de luta e enfrentamento dos racismos cotidianos, foi a sua família e o movimento negro que a fortaleceram na confiança de si diante das práticas de negação de sua afrodescendência, para impulsionar práticas positivas. Porém, é preciso repensar quando, enquanto família, não nos sentimos acolhidas/os. Essa possibilidade, de estar acolhendo e sendo acolhida/o, nos remete à conscientização daquilo que aprendemos e nos propomos a aprender. Sem essa, será 
difícil ensinar/aprender novas positividades, será difícil reforçar aspectos em nós que nos eleva e nos põe a questionar quando vivenciamos situações que nos interditam.

Cada uma dessas mulheres nos ensinou, com suas narrativas, a tentarmos nos encontrar de maneira positiva e carinhosa nas sendas traçadas por nós durante nossas aprendizagens e conscientizações no mundo, a nos sentirmos para além do racismo que nos tenta cegar e calar. Com elas, entendemos sobre a consciência ingênua que Freire (1979) descreve como aquela que não busca aprofundamento dos fatos, e sobre a consciência crítica, que é aquela questionadora, problematizadora dos fatos. Aprendemos a ter ousadia, para não nos contentarmos com o rebaixamento racista, machista e classista.

Foi com intuito de "fazer e pensar sobre o fazer" (FREIRE, 2011, p. 39), que foram levados para a turma vários livros sobre Arte de tradições africanas (esculturas, tecelagem e pinturas). Com as leituras escritas e imagéticas, cada partícipe se tornava um corpo-participante e pensante/questionador, aquele que, segundo Antonieta Antonacci (2009), não pode ser mais silenciado, assim como os corpos das afros diásporas, corpos que precisam saber que têm e se animam por ter história, cultura, arte, escrita, epistemologias, saberes e conquistas. Pois, por muito tempo, as lâminas cartesianas do racismo, como projeto de subalternização de corpos, em nome do moderno-progresso, nos ignoraram e tentaram desfragmentar esse conhecimento e se apossaram dele para seu próprio benefício genocida, epistemicida e colonial.

Antonacci, assim como Freire, nos lembra que é preciso pensar sobre aquilo que parece estar cristalizado como normal. É preciso uma tal curiosidade epistemológica, um aprender com uma reflexão sobre a nossa assunção subjetiva e disponibilidade para mudança como transformação (FREIRE, 2011). É preciso escutar, ouvindo as nossas próprias narrativas de corpos-memórias que participam e pensam suas práticas; desfazer crenças sobre registros escritos, sonoros e iconográficos que mais nos alienam do que nos contam de fato quem fomos e somos (ANTONACCI, 2009). Retomamos o conceito de corpos-memórias também porque entendemos, ainda com Antonieta Antonacci (2009), que as duas mulheres acionaram as memórias para narrar suas experiências de serem afrodescendentes e estudantes de moda em um país racista. É também isto que queremos provocar com a próxima imagem. 
Figura 5: Estudante do Atelier de Moda Afro procurando informação em livro sobre arte tradicional africana para inspiração da peça de moda afro. Teresina, 2019.

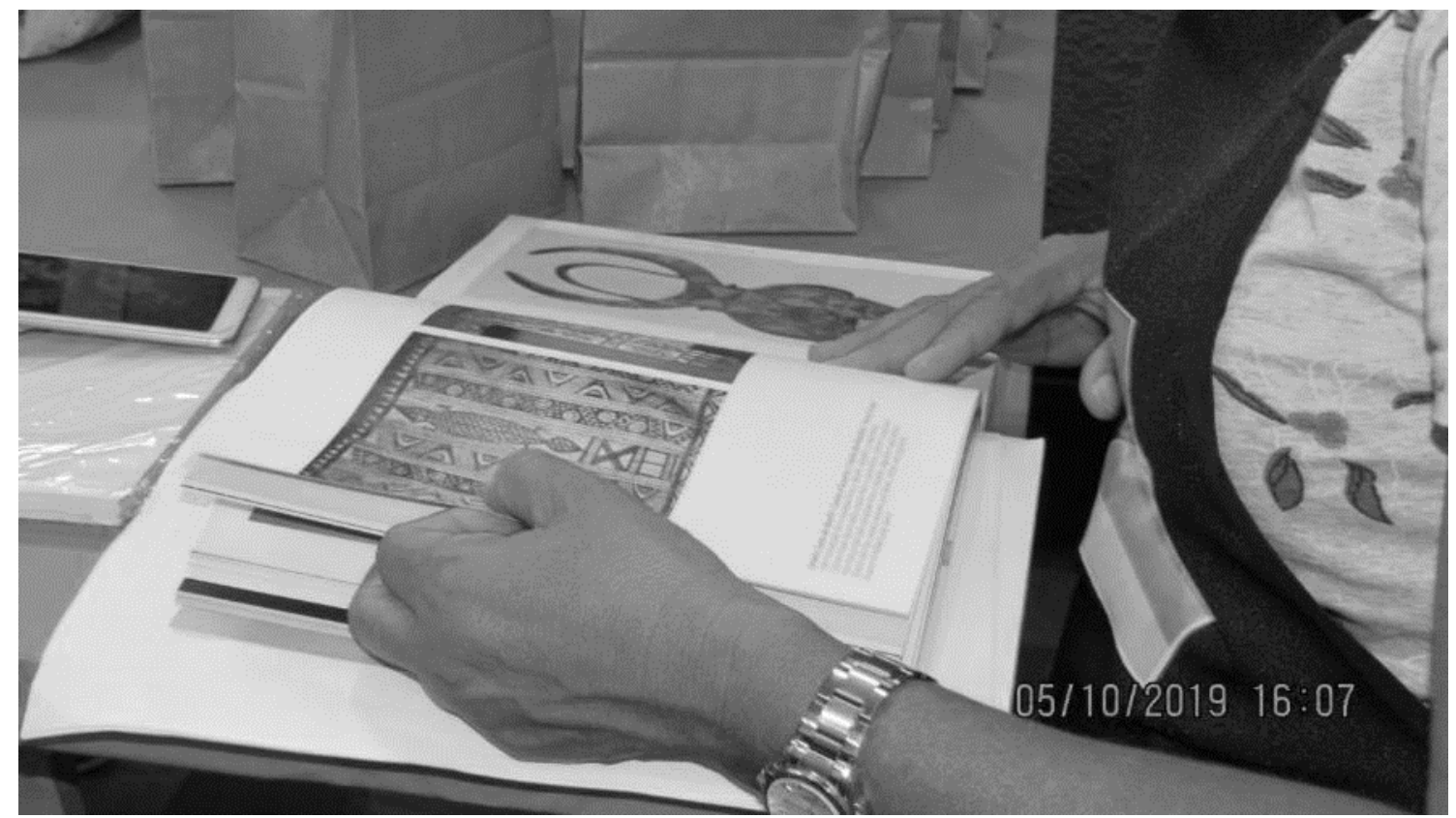

Fonte: Foto de Wendel Aguiar, 2019. Acervo dos autores.

Acima, vemos a foto de uma estudante no Atelier tentando encontrar elementos basilares para o projeto/design de sua peça para o desfile de moda afro. Um momento posterior às rodas de conversas, quando foram discutidos temas a respeito dos povos africanos que vieram escravizados para o Brasil e seus descendentes, conversas que desembocavam quase sempre no cruel racismo brasileiro e suas consequências.

Cada partícipe, nestas conversas, foi considerada/o como corpo-memória, pois narravam suas experiências mexendo em suas memórias para encontrar a si mesmas/os em suas histórias compartilhadas. Dentre essas pessoas, estudantes, estavam duas mulheres afrodescendentes, Esquadro e Miçanga (seus codinomes na pesquisa), que, após todo esse processo de prática educativa mútua, nos procuraram para conversar sobre algumas histórias tecidas e (re)pensadas em suas vidas.

Nas suas narrativas, ou seja, nas histórias mexidas nas suas memórias (lugar de encontros e novas/velhas descobertas, lembranças e esquecimentos), encontramos espécies de categorias com as quais iremos dialogar agora.

\section{CORPOS DAS NARRATIVAS, AS ANÁLISES DIALOGADAS}


Para tal diálogo, mais uma vez lembramos de Paulo Freire), quando este nos instiga a pensar sobre uma das tarefas da prática educativo-crítica: "propiciar as condições em que os educandos em suas relações uns com os outros e todos com o professor ou a professora ensaiam a experiência profunda de assumir-se" (FREIRE, 2011 p. 22). Mexer na memória, narrando a si nas relações com outras histórias de corpos-memórias, faz com que tenhamos a experiência profunda de acreditar e querer assumir-se enquanto sujeito de nossa história, muitas vezes, aprendida a ser negada.

O processo de desenvolvimento de assumir-se, ou seja, da assunção de ser sujeito de sua história positivada, fez muita diferença ao escutarmos as narrativas das duas mulheres. A partir dessas narrativas orais colhidas nas conversas classificamos as categorias presentes nas falas com o seguinte diagrama:

Figura 6: Categorização das narrativas de Esquadro e Miçanga (partícipes do Atelier de Moda Afro), Teresina, 2019.

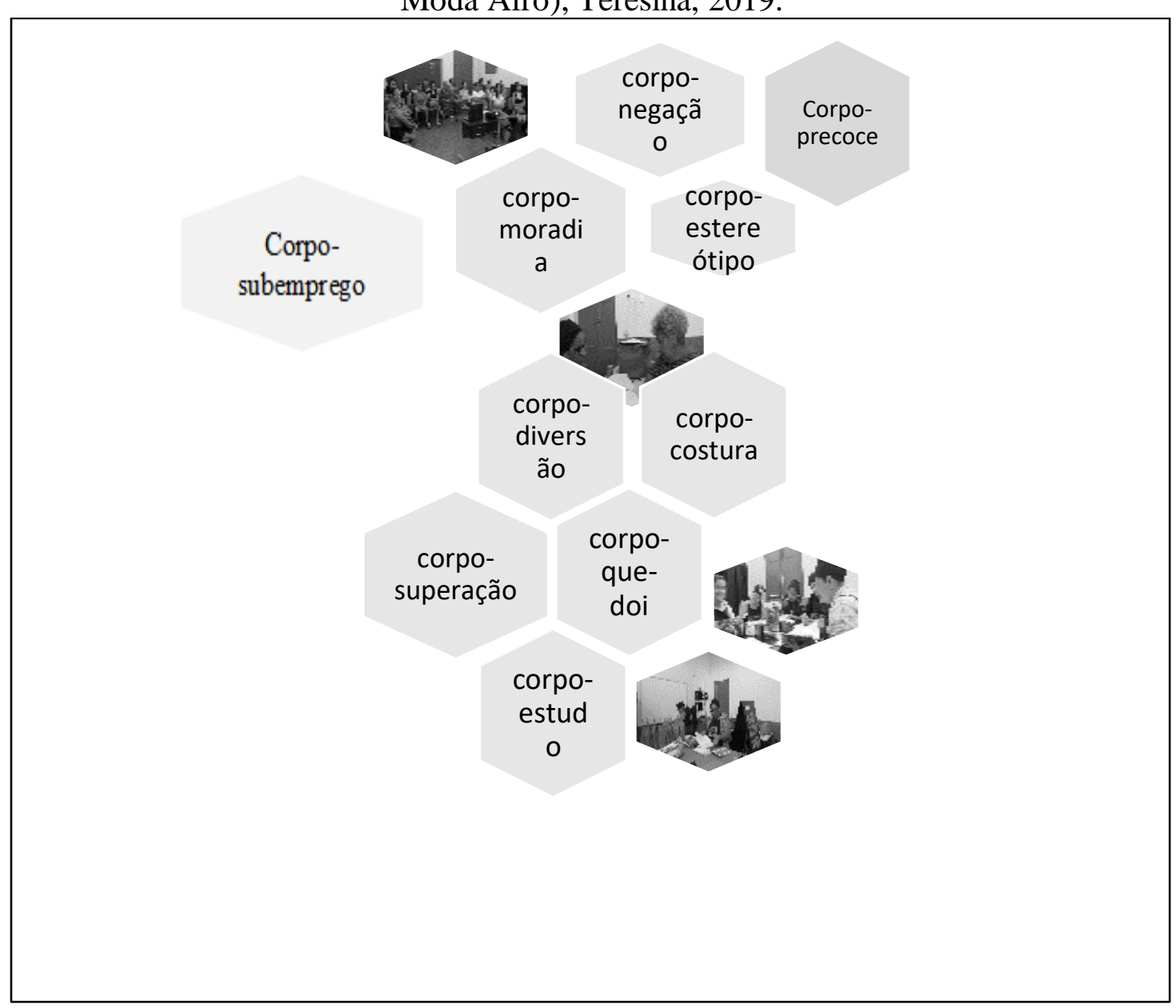

Fonte: Produção dos autores do texto. Teresina, 25 de maio de 2020. 


\section{Oensinomern}

A Figura 5 é uma representação das categorias tecidas no nosso diálogo analítico sobre as narrativas de Miçanga e Esquadro. Nele incluímos também algumas fotos de momentos no Atelier. Este diagrama é uma espécie de colmeia no sentido das muitas experiências contadas como enxame de vivências de significados específicos; de identificações com as outras histórias tecidas no Atelier, bem como fora deste. Através dele, percebemos a atenção e a tensão na maneira como a conscientização foi sendo construída. A oralidade, para a exposição das narrativas de vida, funcionou também como uma forma de "terapia", segundo uma das participantes, no final de seu depoimento.

Ao externar as histórias contadas, cada corpo-memória trouxe muitas curiosidades para nós. Foi assim que nos questionamos que corpos são esses no cenário que existem.

Esse e qualquer um outro trabalho que possa tornar pessoas mais críticas com relação às questões raciais é justificável, pois o racismo faz com que as pessoas não se sintam inteiras. A trajetória dessas mulheres importa para um sistema de educação institucional, que ainda carrega em si um racismo estrutural? Ser costureira, estudante em um curso superior de moda e participante de uma oficina de moda-afro para mulheres que passaram por muitas dificuldades e ainda tinham que ter consciência do racismo que sofriam cotidianamente, é ser exemplo de incrível resistência. A história dessas mulheres são maneiras de enfrentamento e consciência de um racismo que a todo momento destrói. São também incríveis vitórias diante dos seus contextos. Adiante trabalharemos cada tópico ou categoria do diagrama apontado na Figura 6 acima.

Os corpos-memórias acionaram experiências vivenciadas e nos instigaram a entender como o Atelier, uma intervenção, possibilitou narrativas de conscientização crítica sobre o racismo que cada uma das partícipes foi percebendo em momentos cruciais de suas histórias de vida.

O primeiro corpo é o corpo-negação dos esforços empreendidos. Nesta categoria encontramos o seguinte trecho:

A promoção pra ser porteiro, estava em cima da mesa dele. E ela foi arrumar a mesa e viu a promoção, né. Só que a promoção é, já estava engavetada, e ela viu. 
Era a forma que eles usavam, né. E ela viu a data. Que é o prazo que tinha pro meu avô se apresentar, né. E foi essa questão que ela levantou, porque além dela, como ela era uma funcionária mais antiga, do que o meu avô, ela já tinha percebido que era por ele ser negro. (Esquadro, Transcrição de áudio, linhas 8590, 17/04/2020).

Quando o avô de Esquadro foi informado de sua promoção não se acovardou, procurou a chefia e assinou sua promoção, se tornou porteiro da instituição, só que isso não foi tão fácil, ele ficou muito triste pelo racismo sofrido, chorou muito e buscou na religiosidade o acalanto. Segundo a neta, sempre que ele tocava no assunto dizia ter procurado na igreja a paz para conter aquele sofrimento. Talvez possam ter outras causas que geraram este sofrimento, mas Grada Kilomba nos diz que esse sofrimento é provocado pelo racismo, que essas cicatrizes ficam para o resto de nossas vidas e são negligenciadas, desvalorizadas pelas outras pessoas que não tem as mesmas experiências (KILOMBA, 2019). Ela se refere às tensões nas experiências de afrodescendentes pertencentes ao continente europeu, o que não é diferente aqui no Brasil.

Mais adiante, Esquadro nos conta de um ocorrido com a avó, no qual o episódio de racismo acontece entre os próprios pares, entre pessoas de mesma cor/raça e mesma condição social. Ela relata:

As roupas muito brancas, minha vó era muito limpa, muito zelosa com as coisas dela. E ela disse assim, é, "a senhora trabalha na casa de quem?” Aí a minha vó, "eu não trabalho na casa de ninguém, essas roupas são minhas". Aí minha vó deu as costas e saiu. Ao sair, a mulher disse assim, "não tem coisa pior no mundo, do que negro querer ser patrão" (Esquadro, Transcrição de áudio, linhas 29-33, 17/04/2020).

O racismo está tão arraigado que atitudes como essa acontecem corriqueiramente, fazendo-nos acreditar que nosso lugar, enquanto afrodescendentes, é o de servir, que não existe a opção de ser servido ou do cuidar de si. Sílvio Almeida, em "Racismo Estrutural", afirma que: "o racismo como ideologia molda o inconsciente" (ALMEIDA, 2019, p. 64). Ele explica que a ação das pessoas, ainda que conscientes, acontece de forma inconsciente. A forma, como esses indivíduos se reconhecem enquanto sujeitos autoconscientes, como eles alicerçam seus afetos, é constituída por padrões racistas fincados no imaginário e em práticas sociais cotidianas (ALMEIDA, 2019). Podemos fazer uma ponte do pensamento de Almeida com os escritos de Lélia Gonzalez (1984), quando a autora nos descreve que a memória desbanca a consciência. Mas, de 
qual consciência Gonzalez nos fala? É a consciência de uma normatividade simplista, que faz de tudo para esqueçamos nossa história e para que as nossas narrativas fiquem sufocadas. Entretanto, escreve Gonzalez (p. 226): “[...] a memória tem suas astúcias, seu jogo de cintura: por isso, ela fala através das mancadas do discurso da consciência".

Agora, se lembrarmos o que é conscientização para Paulo Freire (1979), estaremos nos reportando à memória de Lélia Gonzalez. Pois, vejamos o que ele nos escreve:

Estes debates, realizados nos Círculos de Cultura, com a ajuda dos educadores especialmente preparados para este trabalho de animação, revelam-se imediatamente como um meio bem poderoso e eficaz de conscientização, capaz de transformar radicalmente a atitude frente à vida. Muitos dos que participaram deles afirmaram, durante os debates e as situações, que "não lhes era mostrado nada de novo, mas que se lhes refrescava a memória", e isto os fazia felizes. "Faço sapatos - disse uma vez um deles - e agora descobri que tenho o mesmo valor que o homem instruído que faz livros." (FREIRE, 1979 p. 29).

A intervenção, com as aulas ocorridas no Atelier, gerou naqueles partícipes os mesmos sentimentos daquele homem que descobriu, nos Círculos de Cultura Freirianos, a importância social do seu trabalho, pois esses discentes se sentiram valorizados. Estar ciente disto não é algo tão simples para quem viveu boa parte da vida sendo subalternizado, inclusive entre seus pares.

O segundo elemento do Diagrama (Figura 6) é o corpo-moradia. Com ele, nos perguntamos: Estamos cientes das mazelas provocadas pelo racismo e cientes também dos benefícios econômicos deste para as classes dominantes que moram bem, em lugares e ambientes favoráveis para si? Basta retomarmos aos dados iniciais deste texto para termos uma amostra de quem não mora bem. Estas mazelas trazem às sociedades as condições de vida extremamente discrepantes, visto que, enquanto uns vivem na riqueza, outros amargam na extrema pobreza. Muito do que vivemos hoje é consequência do colonialismo, que teve e tem, como base, como mola propulsora, o racismo. No dizer de Anibal Quijano: “A colonialidade do poder, isto é, a ideia de 'raça' é o fundamento do padrão universal de classificação social básica e de dominação social”' (QUIJANO, 2002 p. 1), a qual nos acostumamos e achamos normal. É o que fica marcado na fala de Miçanga, quando essa descreve a minúscula moradia, conseguida por uma amiga, e onde ela foi morar com sua mãe inválida, após a morte do pai, mais três irmãos menores de 
idade, uma situação desumana para uma jovem de apenas dezenove anos, sem trabalho fixo.

E aí o que me chocou foi a história, que eu acho que chocou ela [a mãe] também, finalizando, foi que, no dia seguinte, a casa era muito pequenininha, era só um quartinho, uma salinha, tudo muito pequeno, acho que não dava seis metros, acho que no máximo dava uns cinco metros, a casinha inteira, né. (Miçanga, Transcrição de áudio, linhas 352-355, 22/04/2020).

A seguir, em concatenação com a fala acima, ela relata a forma como ela e seus irmãos/ã eram tratados/as, de forma estereotipada, desrespeitosa - desvelando o terceiro corpo, corpo-estereótipo negativo:

Não chamavam a gente pelo nome, né. Chamava negra da canela seca, era olho de bomba, minha irmã menorzinha que é a mais moreninha de todas nós, tinha o cabelo bem cacheadinho, o cabelo não crescia, era redondinho, todo tempo aquele cacheadozinho, crespinho, né. Aí chamavam cabeça do motor... ehhh... sempre era assim. (Miçanga, Transcrição de áudio, linhas 124-128, 22/04/2020).

Depois, passada essa história, as vezes eu penso, e quanto mais penso eu lembro assim toda, que o racismo vinha embutido desde quando a gente passou a morar lá né. Porque, nunca chamaram a gente pelo nome. Chamavam é, negrinha da canela seca... "ei nego da canela seca vem aqui, vai ali na quitanda comprar isso pra mim". "Ei nega da cabeça de motor, vem aqui, vem fazer isso aqui". Minha irmã foi pescoço duro não, não, nem respondia, né. Mas eu me habituei a chamar a dona lá de madrinha, passei fogo, né, de fogueira, "madrinha". (Miçanga, Transcrição de áudio, linhas 481-487, 22/04/2020).

Chamar alguém pelo nome é, sobretudo, reconhecer sua dignidade e humanidade. É ter consciência de que somos iguais. O nome marca uma ligação com a nossa história (nossas narrativas sobre nós mesmos), mas quando essa história tenta ser apagada a todo custo por uma cultura viciada em práticas colonialistas, nos resta, daqueles que querem perpetuar seus domínios, os apelidos pejorativos. Não foi à toa que fomos chamados pelos europeus de índios e negros.

Essa forma de tratar crianças afrodescendentes nesse país parece já ser naturalizada demais e cinicamente irrelevante. As crianças escutam, se ressentem, não dizem nada, na maioria das vezes, entretanto as marcas ficam para o resto de suas vidas. Não é fácil aceitar e mais difícil ainda é se defender. Djamila Ribeiro, escritora brasileira, militante negra, pontua: 


\section{O}

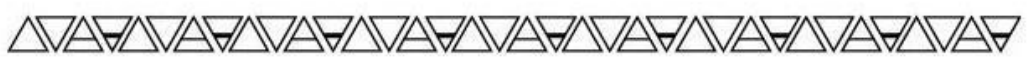

Se para mim, que sou filha de um militante negro e que sempre debati essas questões em casa, perceber essas nuances é algo complexo e dinâmico, para quem refletiu pouco ou nada sobre esse tema pode ser ainda mais desafiador. $\mathrm{O}$ processo envolve uma revisão crítica profunda de nossa percepção de si e do mundo. Implica perceber que mesmo quem busca ativamente a consciência racial já compactuou com violências contra grupos oprimidos. (RIBEIRO, 2019, p. 5).

Esse processo de exploração, essa violência, na maioria das vezes leva a um outro problema mais grave, que é a exploração do trabalho infantil. Nesse quarto corpo, encontramos o corpo-precoce com responsabilidades, é o que nos relata Miçanga sobre todo o esforço feito por ela para livrar seus irmãos do vício provocado por um trabalho pesado, degradante até para adultos, imaginem para crianças. Ela pontua:

O papai sempre nos poupou desses serviços pesados, mas o restante, na hora de pegar os tijolos, levar pra assar, carregar na cabeça, aquelas pilhas de tijolo, é ele sempre procurou ter animais pra ajudar nessas tarefas, mas aí a gente ajudava, carregando os animais, outra hora cuidando. Sempre estava ali do lado dele trabalhando. E eu ficava com muito receio de...meus irmãos, com a doença já de meus pais, né, eu tinha muito receio de ver meus irmãos se acabar tudo dentro dessas... fumar, beber, eu acho que pra suportar todo esse peso, né, eles acabam se envolvendo muito cedo com bebida. E, eu não queria ver meus irmãos dentro dessa situação. Então com a doença de meus pais, eu já comecei a ficar muito preocupada com isso, eu já estava trabalhando, numa gráfica, ganhando muito pouquinho (Miçanga, Transcrição de áudio, linhas 149-159, 22/04/2020).

A gráfica já estava com dificuldade, aí faliu, e foi quando eu comecei a, a trabalhar com a costura, porque de qualquer maneira também precisava ficar em casa pra cuidar de meus pais. Aí comecei a costurar. (Miçanga, Transcrição de áudio, linhas 198-200, 22/04/2020).

Toda a história contada por Miçanga começa quando a família se muda para uma quinta nas margens do rio Parnaíba, onde o pai foi trabalhar como oleiro, fazendo tijolos e telhas. A terra não era dele e ele trabalhava num processo ainda naturalizado por aqui (em terras piauienses, maranhenses, e talvez nordestinas e, porque não dizer, brasileiras) chamado de meia, o que nos leva a entender que os meeiros dividem os lucros, só que a coisa não acontece como imaginamos, trata-se de um processo de exploração muito grande. Assim, desvelamos um quinto corpo do Diagrama (Figura 6): o corposubemprego. Vejam o que ela nos relata:

Se ele assasse uma fornalha de tijolo de dez milheiro, dois milheiros já eram do dono da terra, e recebia ali prontinho, não era descontado o suor dele que era pra fazer, se ele tinha pago pra fazer aqueles tijolos, nada era descontado, era limpo 


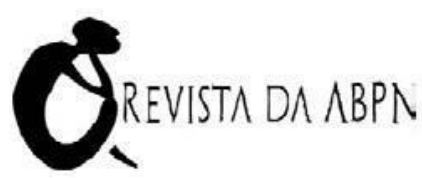

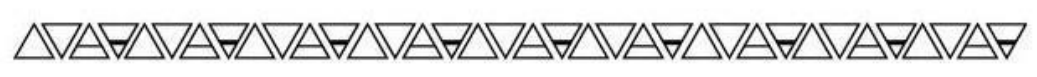

e seco, ele recebia aquele material já empilhado ali, só fazia separar e dizia, isso aqui é de fulano. Se era telha, era do mesmo jeito, aí se ele vendia tinha o lucro dele. Do material do meu pai, ainda ia tirar a despesa de que ele tinha pago pra fazer né, o milho dos animais que ele tinha pra alimentar os animais é [...] essas coisas né. (Miçanga, Transcrição de áudio, linhas 506-513, 22/04/2020).

Ao ler trechos das transcrições da fala da Miçanga, nos vem à tona a fala de Carla Akotirene (2019) quando, ao discutir a questão da interseccionalidade, afirma: “A interseccionalidade permite às feministas criticidade política a fim de compreenderem a fluidez das identidades subalternas impostas a preconceitos, subordinações de gênero, classe e raça" (AKOTIRENE, 2019, p. 37). Miçanga e a irmã sofriam essa tripla opressão, mesmo em momentos que deveriam ser de diversão, pois eram consideradas, pelos patrões de seus pais (donos das terras) e familiares, como negras, pobres, e mulheres menos importantes.

Mais adiante encontramos o sexto corpo, o corpo-diversão.

Quando tinha as festas lá, a gente ficava ali, pelo meio das festas, não como convidado, mais pegando prato, era levando pra cozinha, lavando, no outro dia a gente ia pra lá pra ajudar as filhas, porque eles não tinham empregada, né, ajudar a limpar a casa, encerar a casa, que era aquela cerâmica antiga vermelhinha e aqueles é, ... aquela cerâmica bordada né, que fizemos até um trabalho, ladrilho bordadinho, né. [...] pra gente, aquilo era uma folia né, como se tivesse sonhando em um dia ter uma casa mais ou menos naquele estado de conforto (Miçanga, Transcrição de áudio, linhas 492-500, 22/04/2020).

Essa memória do corpo-diversão nos remete à memória de Gonzalez, pois este é um corpo-memória que desbanca a consciência normativa e simplista de que a "festa" ou a cultura brasileira com sua democracia racial - é para todos. Porém, ao narrar este fato, de uma diversão condicionada à cozinha e aos afazeres, a memória mexe e destrona a "festa". Além disso, encontramos nessa voz um eco de alguém que diz: também queremos nos divertir. Esse é um direito básico a todo cidadão brasileiro. Mas, o que de fato tinha que ser feito era costurar suas próprias diversões dentro do labirinto racial.

Costurar é uma atividade que consideramos importante por vários motivos: sempre tem alguém necessitando desses serviços, você não precisa sair de casa para trabalhar, você tem flexibilidade de adequar esse trabalho com outros, sem contar que é uma atividade agradável e, na maioria das vezes, relaxante. Mas, para muitas mulheres, se tornou necessidade. Foi enveredando por esse caminho que Miçanga começou seu 
processo de profissionalização sem abandonar os estudos. Aqui apontamos o sétimo tópico do Diagrama (Figura 6), que é o corpo-costura. Ela nos conta:

Comecei a costurar, a fazer pequenos consertos, que minha mãe já fazia isso, ela não costurava pra fora, assim profissionalmente, ela ajudava, fazia a roupa de um vizinho, a roupa de uma colega. Inclusive, pra esses donos das terras, ela fazia muita coisa, fazia ...eles costuravam lá as roupas de ir pras festas, das filhas e tudo, e minha mãe era quem fazia os acabamentos, porque ela era muito caprichosa no acabamento manual, né, nos acabamentos das roupas. Então, ela fazia aquelas peças de roupas das filhas irem para as festas e mandava pra minha mãe fazer os acabamentos, que chuleava todo na mão, com aquele ponto bem miudinho, fazia as casas, casas das blusas, casas das camisas, tudo feito à mão. Minha mãe fazia uma casa que eu nunca mais na vida vi uma casa feita daquele jeito, na mão. E aí, eu comecei a fazer esses pequenos consertos, (Miçanga, Transcrição de áudio, linhas 290-301, 22/04/2020).

Falarmos sobre a história de vida de duas alunas, Esquadro e Miçanga, faz com que nos questionemos da mesma forma que Djamila Ribeiro: "o que, de fato, cada um de nós tem feito e pode fazer pela luta antirracista?" (RIBEIRO, 2019, p. 11). Sempre nos questionarmos, pois duvidar sempre daquilo que nos pareça natural, não perder nenhuma oportunidade de falar sobre o tema, são atitudes que nos farão evitar a reprodução dessa violência que privilegia uns e oprime outros.

No corpo-estudo, a oitava categoria do Diagrama (Figura 6), percebemos o não privilégio de poder se dedicar plenamente aos estudos. Passar por tanto sofrimento deixa nos corpos marcas e adoecimentos que provavelmente seriam evitados ou minorados.

Conclui o ensino médio, fiz é, fui escolher curso profissionalizante, técnico em contabilidade, ... mas nunca exerci a profissão, já fui logo virando costureira e aí eu... só retornei agora né, depois de várias tentativas. Aliás, minto, fiz outro ensino médio, mas não cheguei a concluir, que era pedagógico (Miçanga, Transcrição de áudio, linhas 737-741, 22/04/2020).

Aí depois eu fiz o ensino médio com a ...como supletivo, só pra... pra não ficar fora de sala de aula, que eu sempre gostei de, de, de estudar (Miçanga, Transcrição de áudio, linhas 747-748, 22/04/2020).

O corpo-estudo vem intimamente ligado ao corpo-que-dói, o nono corpo, dos irmãos e da família, pois: como estudar vendo as necessidades que precisam ser sanadas? Miçanga nos fala do adoecimento da irmã e da morte do irmão:

E aí era ensino médio, e aí eu, disse que ela poderia sair pra poder fazer o estágio com mais tranquilidade, e ela fez isso, foi fazer o estágio e tudo, mas infelizmente 


\section{Oomame}

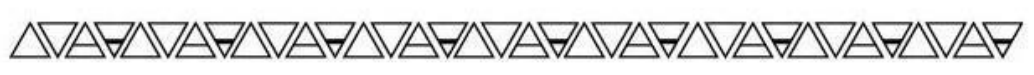

veio adoecer, essa irmã que eu tenho, que tem problema de esquizofrenia. Passou dez anos surtada (Miçanga, Transcrição de áudio, linhas 718-721, 22/04/2020).

[Sobre a sobrinha:] o pai dela faleceu com aneurisma, aneurisma cerebral. E esse último, meu irmão tá com oito ano que faleceu foi, complicação de uma diabete (Miçanga, Transcrição de áudio, linhas 784-785, 22/04/2020).

Tanto a esquizofrenia da irmã, quanto a morte por aneurisma cerebral e por diabete dos outros dois irmãos de Miçanga, foram acontecimentos intimamente ligados a vida extremamente difícil, devido às condições de trabalhos que nunca os permitiram estudar, muito menos a ter trabalho decente, no conceito lembrado no início de texto. Tal trabalho está relacionado à promoção de igualdade, remunerações decentes, liberdades, equidades e seguranças; à garantia de vida digna; e ao cumprimento de desenvolvimento e justiça social.

Apesar de todos os problemas pelos quais Miçanga passou, ela se considera uma pessoa feliz e realizada, nós também comungamos da mesma ideia. Mais que isso, Esquadro e Miçanga são vitoriosas, vencedoras, devido estarem hoje entendendo que suas condições raciais-sociais-femininas nunca as favoreceram, mas terem encontrado maneiras de estarem vivas, estudarem, trabalharem e contarem suas histórias de maneira crítica. Miçanga termina sua narrativa trazendo o corpo-superação, o décimo corpomemória do Diagrama (Figura 6), dizendo:

Oh professora, realmente lembrar disso tudo assim é.... (suspiros)... foi uma terapia. Na verdade, a palavra foi essa, foi uma terapia. Era muita coisinha guardada e, quando a gente já olha isso, depois de um tempo já distante, a gente enxerga que, que venceu, né. Porque só o fato de eu e minhas irmãs, e meus irmãos termos conseguido driblar a situação que a gente vivia num momento de risco, que era de risco, o que se viveu nos anos oitenta. (Miçanga, Transcrição de áudio, linhas 637-642, 22/04/2020).

Passar por tudo que essas duas, Esquadro e Miçanga, passaram, foi um epistemicídio, conceito que foi também desenvolvido por Aparecida Sueli Carneiro (2007) em sua tese de doutorado, e que demonstra toda a perversidade do racismo. Referindo-se ao processo escolar brasileiro, ela pontua:

Alia-se nesse processo de banimento social a exclusão das oportunidades educacionais, o principal ativo para a mobilidade social no país. Nessa dinâmica, o aparelho educacional tem se constituído, de forma quase absoluta, para os racialmente inferiorizados, como fonte de múltiplos processos de aniquilamento 


\section{0}

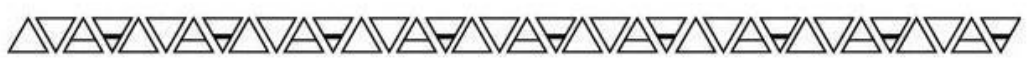

da capacidade cognitiva e da confiança intelectual. É fenômeno que ocorre pelo rebaixamento da autoestima que o racismo e a discriminação provocam no cotidiano escolar; pela negação aos negros da condição de sujeitos de conhecimento, por meio da desvalorização, negação ou ocultamento das contribuições do Continente Africano e da diáspora africana ao patrimônio cultural da humanidade; pela imposição do embranquecimento cultural e pela produção do fracasso e evasão escolar. A esses processos denominamos epistemicídio (CARNEIRO, 2005 apud CARNEIRO, 2007 p.1).

A consciência de apoderar-se de sua história e assumir-se enquanto valorização de tudo que foi negado a si mesmas é o que podemos (re)aprender. "Nessa perspectiva, todas as pessoas são reconhecidas como depositárias de saberes (contextualizados) e práticas (relevantes) - tecidas como fios de memórias" (BOAKARI; MACHADO; SILVA, 2014, p. 115). Consideramos as duas mulheres, futuras designers de moda, mulheres de sucesso, mesmo ainda não tendo concluído seu curso de Moda. Nesse sentido, nos perguntamos: "Quem é ela e como outros da sociedade a definem [...]"? (BOAKARI, 2015, p. 28). Para responder este, e outros questionamentos referentes a nossa preocupação no texto, é que continuamos a pesquisar com mulheres/homens afrodescendentes.

\section{ALGUNS BENEFÍCIOS - CONSIDERAÇÕES FINAIS}

A partir das provocações sobre quem são essas mulheres, e o que nos ensinaram, adentramos algumas considerações finais querendo dar visibilidade para alguns benefícios sentidos durante as análises, enquanto dialogávamos sobre esses. Desta maneira, faremos uma relação desses benefícios e deixaremos o debate aberto para possíveis colaborações sobre as linhas e os botões costurados aqui, bem como os arremates (des)feitos.

Com os dez corpos-participantes ou corpos-memórias acima descritos, encontramos material dialógico para que pudéssemos analisar e sintetizar os aprendizados enquanto possibilidades interpretativas nesse momento. Assim, pudemos retomar a questão: O que o atelier causou como benefício em dois corpos-participantes, a partir da oficina que vivenciaram como processo de conscientização, que os fizeram narrar os sacrifícios e as dores geradas pelos racismos, os quais antes não percebiam? 
Não obtivemos uma só resposta, pois, dos diálogos expostos e das consciências trazidas em cada trecho narrado, encontramos uma prática educativo-crítica que causou os seguintes benefícios: vivências dessas memórias; acionamento de ações criativas; elementos disparadores da consciência; afastamento para pensar; percepção do sentido dos dispositivos (o espaço e aspectos materiais do atelier, as imagens, as pesquisas realizadas, as conversas com debatedores); percepção "terapêutica" do processo; e o tornar-se profissional com consciência crítica sobre a sociedade em que atua. Abaixo pontuamos cada um deles.

1. Vivências dessas memórias: as possibilidades de compor sua narrativa tecendo uma consciência própria e não uma consciência requerida pelo racismo. Foram também momentos que não apenas as duas, Esquadro e Miçanga, mas muitas outras falaram de suas dificuldades, outras vezes de momentos alegres e alguns deles permeados de racismos, questões de gênero, situação econômica, entre outras.

2. Elementos disparadores da consciência: as interações com outros profissionais, como um artista, uma pesquisadora, duas mulheres ativistas, os lugares visitados, as obras pesquisadas, todas as situações que dispararam para que elas narrassem algo de si. Esses disparadores foram percebidos em quase todas as conversas. Por exemplo, uma pergunta/resposta que Miçanga fez quando ela não tinha consciência que estava sofrendo racismo. Em outro momento, ela diz que tinha medo de que os irmãos caíssem em algum vício devido aos sofrimentos percebidos.

3. Afastamento para pensar: a prática de poder parar e pensar sobre o seu fazer. Esta prática foi percebida aqui com nitidez, por exemplo, quando um dos corpos-participantes chega no final da apresentação de um filme e comenta que sua visão agora era outra, se comparada com a primeira vez que assistira o mesmo filme e com suas atitudes anteriores.

4. Percepção do sentido dos dispositivos: a capacidade de acionar a memória e perceber os sentidos que cada momento ou experiência no Atelier provocou em si. Também foi quase unanimidade no grupo, enquanto tecíamos nossas conversas em rodas, a consciência de que esses momentos foram muito importantes para o acionamento de lembranças em que aconteceram 
incidentes de racismos, subalternizações e sofrimentos. Entretanto, elas foram capazes de driblar essas situações e, apesar das cicatrizes, foram capazes de estarem vivas, inteiras, e criando sentido para suas existências, o que provocou rodas de conversas até mesmo depois das experiências do Atelier.

5. Acionamento de ações criativas: todo o processo objetivava a criação de peças do vestuário e acessórios para um desfile de moda afro (as partícipes estavam diante de várias limitações, que não impediu, mas estimulou o processo criativo. Por exemplo, tínhamos apenas tecido de saco branco com largura de apenas $60 \mathrm{~cm}$, tecido que não aceita sublimação, técnica de estampar, muito utilizada no momento. Elas foram capazes de criar tendo como inspiração elementos estudados e discutidos no Atelier, e pouco difundidas em nossas escolas, nos meios de comunicação. Como exemplos: o vestido inspirado nas joias dos povos ashantes, o que demonstra o nível daqueles africanos escravizados que já tinham o domínio de um metal tão precioso como o ouro; o vestido inspirado em Omolu, orixá/divindade dos povos iorubas (um dos maiores grupos étnico-linguísticos da África Ocidental) da cura de doenças infeciosas de pele, que atacavam os africanos escravizados, como é o caso da varíola.

6. Percepção terapêutica do processo: a partir de um trecho falado por Miçanga, observamos a afirmação de que falar de sua história, desses momentos marcantes de sua vida, serviu como uma espécie de terapia, um desabafo tão grande que, ao terminar, ela se sentiu aliviada, talvez por ser ouvida, por poder compartilhar.

7. Tornar-se profissional com consciência crítica sobre a sociedade em que atua: nos muitos relatos ocorridos, a fala das duas partícipes e as colocações durante as rodas de conversas do grupo em geral, nos levam a concluir que essa prática educativa foi capaz de permitir o questionar-se sobre o seu fazer como designers de Moda.

A partir dos sete benefícios que encontramos nas narrativas dialógicas das duas mulheres afrodescendentes, estudantes de designers de moda, percebemos o que o 
trabalho de intervenção de um Atelier de Moda Afro causou no sentido de provocar uma conscientização crítica a respeito do racismo e machismo (esse menos explorado aqui).

É preciso, então, que retomemos aos sentidos de memória, consciência crítica e narrativa, bem como é preciso entender que o racismo nos impede de perceber a necessidade dessas intervenções na área da moda, do ensino e da cultura em geral. Retomando esses elementos compositivos da nossa sociedade, poderemos mexer na nossa prática educativa e proporcionar experiências outras com futuros profissionais. Narrar foi, para esse texto, um mexer nas profundas lembranças e esquecimentos que a memória guarda. A consciência crítica foi possível pela astúcia da memória em fornecer material para decidirmos transformar a vida e a convivência, assumindo ser sujeito de sua história, para superar subalternizações, explorações violentas, as dores das mortes de entes queridos, e as nossas próprias mortes nestas mortes outras.

\section{REFERÊNCIAS BIBLIOGRÁFICAS}

AGÊNCIA IBGE NOTÍCIAS. Pretos ou pardos estão mais escolarizados, mas desigualdade em relação aos brancos permanece. Disponível em: <https://agenciadenoticias.ibge.gov.br/agenciasala-de-imprensa/2013-agencia-de-noticias/releases/25989-pretos-ou-pardos-estao-maisescolarizados-mas-desigualdade-em-relacao-aos-brancos-permanece>. Acesso em: 14 ago. 2020.

AKOTIRENE, Carla. Interseccionalidade. São Paulo: Sueli Carneiro; Pólen, 2019.

ALMEIDA, Silvio Luiz de. Racismo Estrutural. São Paulo: Sueli Carneiro; Pólen, 2019.

ANTONACCI, Maria Antonieta. ÁFRICA/BRASIL: corpos, tempos e histórias silenciadas. Revista do Programa de Pós-Graduação em História. Florianópolis, v. 1, n. 1, 2009, p. 46-67.

ANTONACCI, Maria Antonieta. Corpos Negros em 'Zonas de Contato' Interculturais. In: VELOSO, Monica Pimenta, ROUCHOU, Joëlle, OLIVEIRA, Cláudia de. (org.). Corpo: identidades, memórias e subjetividades. Rio de Janeiro: Mauad X, 2009.

ANZALDÚA, Gloria. Falando em Línguas: uma carta para as mulheres escritoras do terceiro mundo. Estudos Feministas. Florianópolis, Ano 8, n. 1, $1^{\circ}$ Semestre, 2000, p. 229-236. Disponível em: <https://periodicos.ufsc.br/index.php/ref/article/view/9880/9106>. Acesso em: 11 abr. 2020.

CARNEIRO, Aparecida Sueli. Epistemicídio. Portal Geledés, 2014. Disponível em: <https://www.geledes.org.br/epistemicidio/>. Acesso em: 18 ago. 2020.

ESCRITÓRIO DA ORGANIZAÇÃO INTERNACIONAL DO TRABALHO. Perfil do trabalho decente no Brasil. Brasília e Genebra: OIT, 2009. Disponível em: https:<//www.ilo.org/wcmsp5/groups/public/---americas/---ro-lima/---ilobrasilia/documents/publication/wcms_226245.pdf>. Acesso em: 14 ago. de 2020. 
BOAKARI, Francis Musa. Mulheres brasileiras afrodescendentes de sucesso: o discurso do fazer, fazendo diferenças. In: BOAKARI, Francis Musa et al. Educação, Gênero e Afrodescendência: A dinâmica das lutas de mulheres na transformação social. Curitiba, PR: CRV, 2015, p. 21-45.

BOAKARI, Francis Musa; MACHADO, Raimunda Nonata da Silva; SILVA, Francilene Brito da. Roda Griô - conquistas, experiências e desafios: aprender com o apreender fazendo. Revista Plures Humanidades, v. 15, n. 1, 2014, p. 109-126.

CUNHA JUNIOR, Henrique. Afrodescendência e africanidades: um dentre os diversos enfoques possíveis sobre população negra no Brasil. Interfaces de Saberes (FAFICA. Online). 2013, p. 1424.

FREIRE, Paulo. Conscientização: teoria e prática da libertação, uma introdução ao pensamento de Paulo Freire. São Paulo: Cortez \& Moraes, 1979.

FREIRE, Paulo. Pedagogia da Autonomia: saberes necessários à prática educativa. São Paulo: Paz e Terra, 2011.

GONZALEZ, Lélia. Racismo e Sexismo na Cultura Brasileira. Revista Ciências Sociais Hoje, ANPOCS, 1984, p. 223-244. Disponível em: $<$ https://edisciplinas.usp.br/pluginfile.php/4584956/mod resource/content/1/06\%20\%20GONZALES\%2C\%20L\%C3\%A9lia\%20\%20Racismo_e_Sexismo_na_Cultura_Brasileira\%20\%281\%29.pdf>. Acesso em: 29 jul. de 2020.

KILOMBA, Grada. Memórias da Plantação: episódios de racismo quotidiano. Lisboa: Orfeu Negro, 2019.

PAIVA, Vera Lucia Menezes de Oliveira e. A pesquisa narrativa: uma introdução. Revista Brasileira de Linguística Aplicada, Belo Horizonte, Faculdade de Letras, v. 8, n. 2, 2008.

RIBEIRO, Djamila. Pequeno manual antirracista. São Paulo: Companhia da Letras, 2019.

QUIJANO, Aníbal. Colonialidade, poder, globalização e democracia. Novos Rumos, Ano 17, n. 37, 2002, p. $04-28 . \quad$ Disponível em: $<$ https://revistas.marilia.unesp.br/index.php/novosrumos/article/view/2192/1812>. Acesso em: 18 ago. de 2020.

SILVA, Maria Lucia da e PERUZZO, Maria Ondina da Silva. Enfim ... Por que a campanha saúde mental da população negra importa! In: Revista da ABPN, v. 12, n. Ed. Especial, Caderno Temático: "III ANPSINEP - Articulação Nacional de Psicólogas/os Negras/os e Pesquisadoras/es", 2020, p. 152-187. Disponível em: <https://abpnrevista.org.br/index.php/site/issue/view/42>. Acesso em: 12 nov. de 2020.

Recebido em: 26/01/2021

Aprovado em: 06/07/2021 